\title{
From Family Doctor to Student Preceptor in the Brazilian Unified Health System: Experience Report
}

\author{
De Médico de Família a Preceptor de Estudantes no Sistema \\ Único de Saúde: Relato de Experiência
}

Daniel Almeida de Oliveira ${ }^{I}$ (D) Eder Viana de Souza $a^{I}$ (D)

\section{KEYWORDS}

- Primary Health Care.

- Learning.

- Medicine.

- Family Health.

Introduction: This article reports the experience of a physician, specialist in Family and Community Medicine, who works in a Basic Health Unit in the southern region of the city of São Paulo, in the Primary Health Care of the Unified Health System, when he became a Preceptor of Medical students at Universidade São Caetano do Sul. Method: The students learned about the typical structure of a Basic Health Unit. They learned how to acquire the medical history during anamnesis, under supervision, and the physical examination, as they acquired the necessary skills. They also learned how to request complementary examinations. With this training, they learned how to apply the clinical method during practice. The students also learned the competence to apply the clinical method in uncontrolled environments through the home visit, which also made it possible to know the reality of the patient in loco. The follow-up of families and the index cases for a few years gave the students the opportunity to experience the different care cycles of the Family Health Strategy, including the question of death, which started in the socio-family context. They also participated and carried out assistance and knowledge transmission groups for the community, in which students were able to train communication and adaptation at the population level. They met and participated in the team meetings, which allowed showing the weekly planning of activities, the interdisciplinary discussion of more complex cases and the created strategies. Results: The promising results of the Active Methodologies based on student autonomy, in relation to the learning process, are applied to the teaching of Medicine in clinical practice environments, since the contact with reality improves learning, challenges the students to research and reflect with autonomy to think about what they must do with the established learning goals and teaches them to use previous experiences to interrelate new knowledge with previous information through Evidence-Based Medicine and reflect on medical practice. Conclusion: Comments are also made on the National Curricular Guidelines, which request the inclusion of the medical student within the scope of the Unified Health System, aimed mainly at Primary Health Care learning. 


\section{RESUMO}

\section{PALAVRAS-CHAVE}

- Atenção Primária à Saúde.

- Aprendizagem.

- Medicina.

- Saúde da Família
Introdução: Neste artigo, é relatada a experiência de um médico especialista em Medicina de Família e Comunidade, que trabalha em uma unidade básica de saúde da região sul do município de São Paulo, na atenção primária à saúde do Sistema Único de Saúde, ao se tornar preceptor de estudantes de Medicina da Universidade São Caetano do Sul. Método: Os estudantes conheceram a estrutura típica de uma unidade básica de saúde e treinaram a confecção da entrevista médica, sob supervisão, e do exame físico, à medida que adquiriam as competências necessárias. Treinaram ainda o pedido de exames complementares. Com isso aprenderam na prática a aplicar o método clínico. Os estudantes também treinaram a competência de aplicar o método clínico em ambientes não controlados por meio da visita domiciliar, o que lhes permitiu também conhecer a realidade do paciente in loco. Por meio do acompanhamento de famílias e de casos-índice realizado durante alguns anos, os estudantes puderam conhecer os diferentes ciclos de atendimento da Estratégia Saúde da Família, inclusive a questão da morte, que se inicia no contexto sociofamiliar. Os discentes também atuaram em grupos de orientação e transmissão de conhecimento para a comunidade e puderam treinar a comunicação e a adaptação referentes à população atendida. Participaram de reuniões de equipe, nas quais vivenciaram o planejamento semanal das atividades, a discussão interdisciplinar de casos mais complexos e as estratégias criadas. Resultados: Obtiveram-se resultados promissores com o uso das metodologias ativas que se baseiam na autonomia do estudante ante o processo de aprendizagem. Essas metodologias são aplicadas ao ensino da Medicina em ambientes de prática clínica, pois o contato com a realidade melhora o aprendizado, desafia o aluno a pesquisar com autonomia a fim de entender com clareza o que fazer com os objetivos de aprendizagem estabelecidos, ensina a usar experiências pregressas para inter-relacionar novos conhecimentos com os conhecimentos prévios, por meio da Medicina Baseada em Evidências, e refletir sobre a prática médica. Conclusão: De acordo com as Diretrizes Nacionais Curriculares, a inserção do estudante de Medicina no âmbito do Sistema Único de Saúde é imprescindível para que ele possa adquirir os conhecimentos necessários para atuar sobretudo na atenção primária à saúde.

Received on 9/9/19

Accepted on $7 / 23 / 20$

\section{INTRODUCTION}

The National Curriculum Guidelines (NCG) make it clear the inclusion of the medical student into the scope of the Brazilian Unified Health System (SUS) for mainly Primary Health Care (PHC) learning and make the curricula flexible, which will adapt them to the current scientific knowledge $e^{1-7}$.

Active Methodologies, based on greater student autonomy in the face of the learning process, aim to provide the "learning to learn" method ${ }^{5,8-12}$; challenge the student to research and reflect with autonomy to think about what to do with the established learning objectives and aims to teach how to use past experiences to interrelate new knowledge with previous information; they also try to arouse the students' curiosity and make them bring new things, which would not be considered in classes and by the teacher ${ }^{1,5,8-9,12}$. Learning should be centered on the student and the person, which would lead the student to have greater interest in learning about the individual, and not only about the disease $e^{1,3,5,8-9,11-12}$. It would increase the students' relationship with the other students, teachers and people involved. The curriculum should be integrated, without dividing the basic and professionalization cycles (ideally, the students have contact with practice since their first year, preferably at SUS, where they learn not only the clinical method, but how the system works) ${ }^{1-9,12}$. This would increase clinical resolvability by making the students deal with complex and unique health conditions and problems in a continuous and longitudinal way ${ }^{5-7}$ through Evidence-Based Medicine ${ }^{9-12}$. Didactically, it has been proven that contact with reality improves learning, despite the study of mere theory ${ }^{3}$.

\section{MATERIALS AND METHODS}

This is the report of a personal experience regarding the transition from a Family and Community Physician to Preceptor of Medical Students within the context of Primary Health Care in SUS.

\section{RESULTS}

In 2016, I was invited, through the Associação Saúde da Família (Family Health Association), to be a Student Preceptor at Universidade São Caetano do Sul.

In the beginning, it was a hard task, as I was unaware of the University's Active Method. Gradually, after taking a course and independent studies, I got to know the Active Methodology.

The interns are medical students from a municipal public university, who pay tuition. The majority of students are from the more affluent classes and have never used the Unified Health System. This reality is a great chance to really demonstrate the role of SUS and eliminate stigmas once and for all, such as the one that says the Unified Health System is a service for the poor, for instance.

First, the students get to know the typical structure of a Basic Health Unit, staying for some time in the reception area, vaccination room, wound dressing area, welcoming area, women's health room and collection of preventive exams for cervical cancer, pharmacy, etc.

The Basic Health Unit, in the Family Health Strategy, acts as the gateway to the Unified Health System and should also function as the organization manager of the Health Care Networks ${ }^{13}$.

REVISTA BRASILEIRA DE EDUCAÇÃO MÉDICA

2 44 (4) : e116; 2020 
Gradually, they started to perform the medical interviews under supervision. I instructed them and completed the interviews by asking pertinent questions when they deviated from the main objective and lacked the knowledge.

As for the physical examination, as they acquired the necessary skills, it was performed by them and reviewed by me.

Regarding the complementary exams, students often suggested some, and I added to them and explained the reason for each exam.

Thus, the clinical method of formulating diagnostic hypotheses was tested, analyzing the probability of each hypothesis, the requesting of complementary exams and the patient's return, with a new medical interview and physical examination, often after the treatment related to the most probable evidence-based diagnosis was tested. The probabilities were adjusted according to the treatment effectiveness and the complementary exams.

The reflection in medical practice is an important factor to improve and expand students' learning. Reflection involves critical thinking, exploring emotional and personal experiences, and assessing the impact of actions ${ }^{14}$. Critical thinking is awakened by teaching the evidencebased clinical method, in creating a unique therapeutic project and in adapting and evaluating this project during case evolution. The evaluation of emotional and personal experiences is obtained by discussing them with the students, so they can talk about such experiences and become aware of them. The assessment of the impact of actions is carried out both during the students' learning and knowledge, as well as through the health improvement of the individual being followed-up.

The Home Visit, a distinctive feature of the Family Health Strategy, was a place where we tested the clinical method in relation to the patient's reality. The Home Visit, in addition to generating a "reality shock" for the students (many had never been to a slum - "favela" - and had never seen such poor housing conditions), provided them with the competence to apply the clinical method in uncontrolled environments.

Each student cared for one family during the internship. The families were diversified and there were people at different life cycles: pregnant women, young children, young adults and adults, the elderly, of both genders. The follow-up of families and index cases for some years allowed the students to witness the different care cycles of the Family Health Strategy. For instance, it showed them women of childbearing age who became pregnant, went through puerperium and childcare; patients with risk factors such as diabetes and high blood pressure who progressed to renal failure, ending up on hemodialysis; patients who had an infarction and had to retire from work and one case of death due to infarction. Getting acquainted with death in the traditional medical school method starts by having contact with the corpse for dissection. In the active methodology, it starts in the social-family context, showing not only a "cold corpse" but a person, missed by the relatives and friends, who demonstrate their feelings. It is a more human aspect of witnessing death, an inevitable event in Medicine.

The supervision groups and the transmission of knowledge to the community constituted an enriching space for the students' actions, who were able to train communication, making it accessible to the population, answering doubts and solving small problems, under supervision.

The preceptor's perspective particularly brings, in relation to the teacher's perspective, the medical practice in real situations, under supervision, but with autonomy. When dealing with the reality of medical practice in uncontrolled spaces as a Basic Health Unit of the Family Health Strategy, students exercise the theory they have learned put into practice and acquire the necessary skills to be a general practitioner.

The students' participation in team meetings allowed showing them the weekly planning of activities, the interprofessional discussion of more complex cases, the strategies created through the dialogue of the diverse knowledge from the different health professionals who participated, such as nurses and community health agents.

\section{CONCLUSION}

The internship in Primary Health Care provided students with autonomy and knowledge associated to reality. For me, as a preceptor, it was a fruitful, rewarding and learning experience, because by teaching, you end up learning more.

\section{ACKNOWLEDGEMENT}

To Associação Saúde da Família, for supporting the Preceptorship in the BHUs.

\section{REFERENCES}

1. Brasil. Ministério da Educação. Conselho Nacional de Educação. Câmara de Educação Superior. Resolução nº 3, de 20 de junho de 2014. Institui Diretrizes Curriculares Nacionais do Curso de Graduação em Medicina e dá outras providências [Access in $29 \mathrm{dez}$ 2018]. Available from: http://portal.mec.gov.br/index.php?option=com docman \&view=download \&alias=15874-rces003-14\&category_ slug=junho-2014-pdf\&Itemid $=30192$.

2. Anjos RMP, Gianini RJ, Minari FC, de Luca AHS, Rodrigues MP. "Vivendo o SUS": uma experiência prática no cenário da atenção básica. Rev Bras Educ Med. 2010;34(1):172-83.

3. Adler MS, Gallian DMC. Formação médica e serviço único de saúde: propostas e práticas descritas na literatura especializada. Rev Bras Educ Med. 2014;38(3):388-96.

4. Ciuffo RS, Ribeiro VMB. Sistema Único de Saúde e a formação dos médicos: um diálogo possível? Interface Comun. Saúde Educ. 2008;12(24):125-40.

5. Demarzo MMP, Almeida RCC, Marins JJN, Trindade TG, Anderson MIP, Stein AT, et al. Diretrizes para o ensino na atenção primária à saúde na graduação em medicina. Rev Bras Educ Med. 2012;36(1):143-8.

6. Ferreira RC, Fiorini VML, Crivelaro E. Formação profissional no SUS: o papel da atenção básica em saúde na perspectiva docente. Rev Bras Educ Med. 2010;34(2):207-15.

7. Ferreira RC, Silva RF, Aguera CB. Formação do profissional médico: a aprendizagem na atenção básica de saúde. Rev Bras Educ Med. 2007;31(1):52-9.

8. Costa JRB, Romano VF, Costa RR, Gomes AP, Batista RS. Active teaching-learning methodologies: medical students' views of problembased learning. Rev Bras Educ Med. 2011;35(1):13-9.

9. Spanhol FJ, Farias GF, Souza MV, organizadores. EAD, PBL e o desafio da educação em rede: metodologias ativas e outras práticas na formação do educador coinvestigador. São Paulo: Blucher; 2018. 242 p.

10. El Dib RP. How to practice evidence-based medicine. J Vasc Bras. 2007;6(1):1-4

REVISTA BRASILEIRA DE EDUCAÇÃO MÉDICA

3 44 (4) : e116; 2020 
11. Dent JA. AMEE Guide $n^{\circ}$ 26: clinical teaching in ambulatory care settings: making the most of learning opportunities with outpatients Med Teach. 2005;27(4):302-15.

12. Kozanitis A. Activités pour encourager l'apprentissage actif durant les cours. Bureau d’Appui Pédagogique. Polytechnique Montréal; 2005.

13. Mendes EV. As redes de atenção à saúde. Ciênc Saúde Colet. 2010;15(5):2297-305.

14. Winkel AF, Yingling S, Jones AA, Nicholson J. Reflection as a learning tool in graduate medical education: a systematic review. Journal of Graduate Medical Education. 2017;9(4):430-9.

\section{AUTHORS' CONTRIBUTION}

Daniel Almeida de Oliveira was the main author and Eder Viana de Souza was the co-author and advisor.

\section{CONFLICTS OF INTERESTS}

The authors report no conflicts of interest.

\section{ADDRESS FOR CORRESPONDENCE}

Daniel Almeida de Oliveira. Rua Treze de Maio, 681, Bela Vista, São Paulo, SP, Brasil. CEP: 01327-000.

E-mail:4477dao@gmail.com 